\title{
A QUESTÃO NACIONAL DO ROMANCE LUCÍOLA DE JOSÉ DE ALENCAR
}

\author{
Angela Maria Rubel Fanini \\ Mestre em Literatura Brasileira pela UFPR
}

\section{Resumo:}

Segundo Antônio Cândido, crítico literário, o Romantismo representa o primei ro movimento decisivo para a Literatura Brasileira porque aí o fenômeno literário se organiza enquanto sistema a partir da tríade autor, obra, público - que unidos o constituem, dando-lhe continuidade, sentido. Além disso, o Romantismo também se apre senta empenhado em criar uma literatura nacional registrando a história e os valores locais a partir de uma ótica idealizante. A crítica romântica passa a valorizar as obras cujo objetivo é constituir uma identidade nacional.

Assim, a "brasilidade" passa a ser critério de excelência para as obras li terárias românticas. Refletindo sobre esses fatos, propusemo-nos a analisar como a realidade nacional e os valores importados são abordados e formalizados no romance Lucíola, do escritor romântico José de Alencar. Percebemos em Lucíola a formalização de um cofllito entre o local e o estrangeiro. José de Alencar, ora nitidamente enga jado a uma política de valorização e construção de identidade nacional, enaltece o que é local; ora, seduzido pela ordem burguesa, denigre o que é nacional, exaltando os valores importados. Esse conflito reflete bem a cultura oitocentista presente na sociedade carioca (cenário do romance) em que se entrelaçavam e se digladiavam valo res opostos: o local cuja realidade era do patriarcalismo, aristocratismo, ruralismo, conservadorismo, escravismo e o importado cuja dimensão era dada pelos valores burgueses - liberalismo, industrialismo, espírito revolucionário. Assim, em Lucíola, a dimensão literária, num movimento de aceitação e negação da cor local e do estrangei ro, reflete o universo extraliterário em que forças antagônicas se embatem - a ordem burguesa contra a patriarcal.

O objetivo deste ensaio é analisar como a realidade nacional do Brasil em meados do século XIX se acha presente no romance Lucíola (1) de José de Alencar. A obra alencariana tem sido alvo de inúmeros estudos críticos e, sendo assim, encontramos o nosso objeto de estudo já avaliado, criticado e valorizado por inúmeros discursos competentes ao longo de sua existência, que já ultrapassa mais de um século. Apesar da existência desses ensaios críticos, o presente estudo se justifica à medida que acreditamos que o conhecimento em qualquer nível, e aqui especificamente literário, constitui-se através de um processo dialético de subjetivação do dado exterior. Para o estudioso de literatura se faz mister elaborar um discurso próprio que encontra, nos discursos que o precedem, antes um apoio do que uma limitação. Assim sendo, recuperaremos partes de alguns desses discursos críticos sobre a obra alencariana a fim de com eles dialogar e conseqüentemente aclarar e esclarecer nosso ponto de vista à proporção que acreditamos que cada novo discurso deve estabelecer sua autonomia, desde que essa seja autonomia participante.

Antônio Cândido, em Formação da literatura brasileira (2), caracteriza a obra de José de Alencar a partir da audiência social a que aquela se destina. A classificação da obra de Alencar, efetuada pelo crítico, subdivide a formação do ficcionista em três momentos - a produção para "rapazes", a produção para as "mocinhas" e finalmente a produção para os "adultos". Antônio Cândido estabelece uma linha evolutiva a nível temático, formal e ideológico na obra de Alencar que é marcada por esses três momentos que são definidos e limitados pelo horizonte social dos interlocutores de cada momento:

... o Alencar dos rapazes, heróico, altissonante,

- Alencar das mocinhas, às vezes pelintra, outras quase trágico.

(FLB, p. 222) 
Todavia, há pelo menos um Alencar, menos patente que esses dois, mas constituindo não raro a força de um e outro. É o Alencar que se poderia chamar dos adultos, formado por uma série de elementos pouco heróicos e pouco elegantes, mas denotadores de um senso artístico e humano que dá contorno a alguns de seus perfis de homem e mulher. Este Alencar, difuso pelos outros livros, se contém mais visivelmente em Senhora e, sobretudo Lucíola, únicos livros em que a mulher e o homem se defrontam num plano de igualdade, dotados de peso específico e capazes daquele amadurecimento interior inexistente nos outros bonecos e bonecas.

(FLB, p. 225)

Notamos que a classificação do crítico opera dialeticamente, evitando uma postura dicotômica que estabelece limites rígidos entre um romance e outro. Dentro dessa perspectiva, cada novo romance de Alencar se processa enquanto uma síntese superadora que retoma as experimentações artísticas e as construções ideológicas que o precederam, reelaborando-as num novo contexto que lhes imprime qualitativamente uma nova realidade. Todo romance é uma obra singular, mas se insere num sistema maior e englobante, marcando uma coerência ideológica e formal que perpassa toda a obra alencariana, revelando também uma nítida linha evolutiva que situa os romances Senhora e Lucíola enquanto construções romanescas, pertencentes a uma fase madura do escritor. O romance Lucíola se constitui como legítimo representante dessa última fase do romancista que demonstra total domínio da técnica narrativa, da construção das personagens e da plasmação numa forma artístico-ideológica de recursos, caracteres e temas já utilizados em obras anteriores. Em Lucíola, Alencar opta por uma narrativa urbana, enfocando a questão das relações entre indivíduos historicamente possíveis, vivendo, sofrendo e amando dentro de uma sociedade brasileira fluminense em transformação. Os acontecimentos, as personagens, suas ações e os discursos pelos quais se expressam constroem um painel bastante verossímil da sociedade brasileira de meados do século XIX. Essa relação vital literatura - sociedade nos obriga a pensar a realidade histórica do Brasil do século XIX, especificamente a década de 50, retratada no romance. Portanto, abriremos um determinado espaço neste ensaio para sintetizarmos determinados fatos históricos relevantes para uma melhor interpretação do romance Lucíola.

A independência política do Brasil não trouxe grandes mudanças substantivas à estrutura político-econômica do Brasil-Império, criada nos antigos moldes da exploração colonial. Houve, na verdade, apenas uma reorganização no topo administrativo, passando o poder concentrado e centralizado pela metrópole portuguesa às mãos das autoridades locais, majoritariamente de raízes rurais. A predominância do poder rural que se organiza e se reproduz através da grande propriedade, do mandonismo, da escravidão e do patriarcalismo não se modificou no período pós-declaração da independência. Porém, essa mentalidade rural entrou em choque e conflito com o universalismo da ordem burguesa que chegava da Europa, aportando principalmente nos meios urbanos. São dois mundos que entram em conflito, aclarando no embate, seus antagonismos, suas diferenças, em que o racional se opõe ao tradicional e o citadino e cosmoplita ao regional e ao paroquial. $O$ novo ideário burquês traz em seu bojo idéias e práticas sociais que abalam substancialmente a realidade rural e agrária do Brasil-Império, essencialmente baseada no trabalho escravo. As pressões internacionais, principalmente a inglesa, acabam por desestabilizar a economia agrária brasileira ao exigirem a extinção do tráfico negreiro. Com a implantação e cumprimento das leis de proibição do tráfico, muitas fortunas de base rural entram em decadência em virtude do alto preço que o elemento escravo passa a ser comercializado dentro do país. Por outro lado, grandes fortunas oriundas da comercialização e do tráfico de escravos passam a reorientar e investir seu capital em outras atividades, especialmente as atividades do setor bancário. Em 1851, 
cria-se o Banco do Brasil que segundo fontes históricas, organizou-se a partir do capital, anteriormente utilizado no comércio de escravos. A partir dessa nova realidade econômica instaura-se um nova política, essencialmente burguesa, que organiza, expande e facilita o crédito bancário. Com as facilidades de crédito, a sociedade brasileira passa por um período histórico de vitalidade no âmbito dos negócios. Essa nova realidade econômica possibilita o crescimento e o fortalecimento de uma nova classe de mercadores e comerciantes, na sua grande maioria, não vinculada à nobreza da terra e portanto desprovida de raízes rurais. Essa classe emergente é permeável às idéias modernas e capitalistas vindas da Europa industrial. Porém, o poder políticoadministrativo se concentra, praticamente, todo nas mãos da aristocracia rural que continua fornecendo o modelo por onde hão de se calcar a vida cultural, política, social e econômica da sociedade brasileira. A classe emergente dos comerciantes e mercadores, apesar de se reorientarem pelas novas idéias de mercados, sonham com o poder político e simultaneamente, anseiam equiparar-se à nobreza da terra cujo prestígio secular ainda não fora totalmente abalado. Sendo assim, a sociedade brasileira de meados de oitocentos oscila entre padrões antagônicos de conduta e práticas sociais. Esse combate de posições se agrava devido ao pensamento anti-tradicionalista de boa parte da intelectualidade, gerada pela classe dominante rural. As idéias novas, aceitas por essa intelectualidade, demonstram que o próprio poder ao gerar saber, muitas vezes está trabalhando para a sua própria destruição. Sérgio Buarque de Holanda em Raízes do Brasil (3), analisando a sociedade oitocentista brasileira, salienta a dependência dos centros urbanos em relação ao poder rural, secularmente estabelecido. A família patriarcal, conservadora e tradicionalista monopoliza a vida política do Brasil-Império, e conseqüentemente exerce grande influência sobre os demais setores da vida social:

Procurou-se mostrar no presente capítulo, como ao menos em sua etapa inicial, esse processo correspondeu de fato a um desenvolvimento da tradicional situação de dependência em que se achavam colocadas as cidades em face dos domínios agrários. $\mathrm{Na}$ ausência de uma burguesia urbana independente, os candidatos às funções novamente criadas, recrutavam-se por entre os indivíduos da mesma massa dos antigos senhores rurais, portadores de mentalidade e tendência características dessa classe. Toda ordem administrativa do país, durante o Império e mesmo depois, já no regime republicano, há de comportar, por elementos estreitamente vinculados ao velho sistema senhoral.

(R. B., p. 57)

Essa realidade brasileira oitocentista que descrevemos e que Sérgio Buarque de Holanda nos apresenta na passagem destacada de sua obra Raízes do Brasil é retratada em todo sua complexidade, transformações e antagonismos internos no romance Lucíola de José de Alencar. $O$ autor, as personagens, seus conflitos, o espaço e as ideologias são expressão viva da sociedade fluminense oitocentista. A narrativa elege a década de 50 , especificamente $o$ ano de 1885 e o espaço fluminense como pano de fundo e palco para 0 drama que vivem as personagens. O romance Lucíola expressa o conflito entre as idéias e práticas sociais orientadas por uma ótica capitalista que passa a valorizar o trabalho, o progresso técnico, a igualdade perante a lei e a divisão entre o público e o privado, entre outras coisas. As personagens vivenciam, falam e expressam essa dissonância interna da sociedade brasileira oitocentista dividida entre realidades ora derivadas do patriarcado rural, ora dos padrões burgueses europeus que apesar de encontrarem resistência por parte da mentalidade fechada, secular e preconceituosa da ordem rural, conseguiram desestabilizar essa mesma ordem. A ordem burguesa rompe com a harmonia da sociedade de espírito e práticas rurais, encontrando no próprio meio condições objetivas (a extinção do tráfico de escravos e a reformulação da economia) e subjetivas (o pensamento intelectual antitradicionalista) que passam a sustentá-la e a fortalecê-la. $O$ 
romance Lucíola expressa essa luta entre o velho e o novo, o cosmopolita e a província, caracterizando o mal-estar da classe dominante de raízes agrárias em virtude de sua dificuldade de conciliar moral, econômica e politicamente as idéias, as vantagens e as mudanças trazidas e oferecidas por uma ordem burguesa e o tradicionalismo da ordem colonial de base essencialmente escravocrata. As personagens e o próprio autor apegados à ideologia da classe dominante de base rural, oscilam entre a aceitação e a negação dos novos padrões que começam a se impor e a se disseminar tanto nas relações políticas e econômicas do Brasil-Império quanto no cotidiano das relações sociais, expressando uma realidade bem nacional de transição e transformação, historicamente verificável.

A obra de José de Alencar, incluindo especialmente o romance Lucíola, manifesta e expressa direta e indiretamente claro objetivo de construir, via literatura, uma identidade nacional. Em 1872, prefaciando o romance Sonhos d'Oro (4), o romancista apresenta um plano que teria norteado toda sua produção ficcional. Demonstra que a sua obra objetivou retratar as etapas formativas pelas quais passara o país desde a vida primitiva dos selvagens até a instauração do Segundo Império. Essa sistematização feita "a posteriori" pretende reforçar no nível teórico a ligação de sua obra com a realidade nacional, revelando a intencionalidade de retratar a realidade pré-existente à ficção. Não discutiremos se a obra alencariana se guiou e se limitou realmente por este plano, mas devemos salientar que essa teorização "a posteriori" apenas confirma o que encontramos na produção de Alencar, ou seja, uma consciência histórica, conseqüente, sincera e comprometida com o real que perpassa toda produção literária do escritor cearense. Analisando o prefácio A Sonhos d'Ouro, notamos que na prosa de narrativa urbana, Alencar, teorizando "a posteriori" sobre ela, demonstra clara consciência da impossibilidade da construção artística de uma identidade nacional baseada e entendida unicamente enquanto uma cultura autocentrada, artificial e ufanisticamente harmônica e homogênea. A cultura e a fisionomia nacional, para o romancista, nascem do entrechoque entre os valores locais e os valores importados, modificando-se através da diversificação dos modelos europeus. A cidade, especialmente a sociedade fluminense em Lucíola, apresenta-se como local de coexistência conflitante do localismo e do cosmopolitismo:

Nos grandes focos, especialmente na corte, a sociedade tem a fisionomia indecisa, vaga e múltipla, tão natural à idade da adolescência. É o efeito da transição que se opera, e também do amálgama de elementos diversos. Dessa luta entre $o$ espírito conterrâneo e a invasão estrangeira, são reflexos: Lucíola, Diva, A Pata da Gazela, e tu, livrinho, que aí vais correro mundo com o rótulo de Sonhos d'Ouro. Taxar estes livros de confecção estrangeira, é, revelam os críticos, não conhecer a fisionomia da sociedade fluminense, que aí está a faceirarse pelas salas e ruas com atavios parisienses, falando a algemia universal, que é a língua do progresso, jargão eriçado de termos franceses, ingleses, italianos e agora também alemães. Como se há de tirar a fotografia desta sociedade, sem the copiar as feições?

(SO, p. 7)

Por esse segmento, notamos que José de Alencar apresenta aguçada consciência crítica em relação às interferências e influências culturais européias na sociedade brasileira. Retrabalhando as importações na esfera da vida brasileira, constrói em prosa ficcional uma sociedade apresentada como síntese de tendências estrangeiras e padrões locais, demonstrando que as importações, descontextualizadas da sociedade européia oitocentista, operavam no Brasil-Império de acordo com outras regras. Notamos que tanto em sua produção

teórica quanto ficcional, e aqui, especificamente o romance Lucíola, o romancista oscila 
entre a aceitação e a negação das novas idéias importadas, referentes à moda, hábitos, literatura, política, economia, etc. O repúdio pelo novo ideário que força a sua entrada e estabelecimento na sociedade brasileira oitocentista por parte do escritor pode ser explicado pela própria posição social do romancista. Obviamente que o escritor consegue manter certa autonomia em relação ao pensamento da classe dominante da qual faz parte. Porém, consciente ou inconscientemente acaba expressando no plano ficcional o mal-estar da classe dominante de raízes rurais em relação às novas idéias e práticas sociais burguesas que repudiam o trabalho escravo e conseqüentemente ameaçam a ordem colonial. Outra explicação para o repúdio aos novos valores pode ser entendida pela própria condição do Brasil-Império recém liberto do jugo estrangeiro, necessitando construir e elaborar uma identidade local inexistente, sufocada e depreciada por séculos. A consciência de se viver entre instituições e idéias que são copiadas do estrangeiro e não refletem a realidade local tem acompanhado a intelectualidade brasileira desde, principalmente a Independência política até os nossos dias. A solução tem sido, muitas vezes, inconseqüente, ou seja, elimina-se o que não é nativo e autóctone e com o resíduo tenta-se ou acredita-se elaborar a "verdadeira" e "autêntica" cultura nacional. O crítico, contemporâneo de José de Alencar, Joaquim Nabuco engrossa as fileiras, no século XIX, dos partidários dessa concepção, a um só tempo, ingênua, primária e ideológica do que venha a ser a realidade nacional. O crítico desvaloriza o romance Lucíola, enfatizando-lhe a ausência de cor local, a inadequação à realidade brasileira e classifica o romance como literatura postiça à medida que o considera mera cópia servil do romance A Dama das Camélias de Alexandre Dumas Filho. Joaquim Nabuco é partidário desse nacionalismo xenófobo que trabalha apenas com o resíduo que sobra depois do expurgo de todo o elemento estrangeiro. Exige do escritor José de Alencar que este se oriente unicamente por um ideário e por uma tradição nacional, não consciente de que ele próprio, enquanto crítico se nutre de posturas críticas literárias importadas, como - Naturalismo e o Realismo. Em A polêmica Alencar-Nabuco (5) destacamos uma passagem em que Joaquim Nabuco critica o romance Lucíola:

A originalidade de Lucíola é nenhuma; a cor local é falsa; o Rio de Janeiro não éo que o autor nos descreve; o desenho é medíocre...

(PA-N, p. 136)

Lucíola não é senão a Dame aux Camélias adaptada ao uso do "demi-monde" fluminense; cada novo romance que faz sensação na Europa tem uma edição brasileira dada pelo Sr. José Alencar que ainda nos fala da originalidade e do "sabor nativo" dos seu livros.

(PA-N, p. 135)

Notamos que a visão do nacional na literatura brasileira de Joaquim Nabuco é bastante estreita e limitada. Tocando na questão da cópia servil opõe o original ao imitado e o nacional ao estrangeiro, traçando fronteiras rígidas que na prática são impensadas e também reforça o mito do original, elevado à categoria absoluta e inquestionável. A visão social da realidade nacional de José de Alencar expressa tanto no prefácio ao romance Sonhos d'Ouro quanto nos romances e especialmente em Lucíola se contrapõe à visão de Joaquim Nabuco à proporção que o nacional refletido e refratado na literatura de José de Alencar não existe enquanto isolado das interferências estrangeiras. $O$ romancista ao responder as críticas de Joaquim Nabuco confirma, uma vez mais, que a sua postura literária se orienta por uma política de interação, do diálogo e do conflito entre a realidade nacional e os valores estrangeiros. José de Alencar, mesmo enfatizando as diferenças entre o romance Lucíola e o romance A Dama das Camélias e repudiando uma semelhança entre eles bastante clara, não sucumbe a uma ideologia nacionalista estreita. José de Alencar entende o romance Lucíola como uma refutação ao romance francês, admitindo, portanto, um diálogo entre eles, que se processa no nível da réplica, apontando para uma continuidade do estrangeiro no nacional e não para uma ruptura. Assim procedendo, José de Alencar também repudia a visão estreita que desvaloriza a cópia como secundária, erigindo o mito do original que dentro de uma concepção 
nacionalista limitada, transforma o original no autêntico nacional, não conspurcado pelos valores estrangeiros:

Essa acusação vaga de plágio é tudo quanto há de mais fútil; mas assenta bem no folhetinista. A Dame aux Camélias, esta sim,não foi mais do que a ressureição de Manon Lescault. Alexandre Dumas Filho remoçou o romance de Prévost, dando-Ihe o encanto de seu estilo. Nenhum crítico, porém, desmereceu o seu livro por causa da semelhança da fábula. Lucíola, bem longe de ser imitação da Dame aux Camélias é, ao contrário, sua cabal refutação. Alexandre Dumas quis provar no seu livro que a mulher podia regenerar-se pelo amor e para o amor; que a afeição verdadeira e sincera, arrancando a pecadora ao seu passado, restituía-lhe a felicidade da posse mútua. Lucíola foi escrita em contestação dessa tese fisiológica. Seu sentimento foi provar que, se a mulher pode regenerar-se pelo coração, rara vez poderá regenerar para o amor feliz; porque nas mais ardentes efusões desse amor achará a lembrança inexorável de seu erro.

(PA-N, p. 150)

A atividade literária no Brasil, na época de José de Alencar, estava estritamente condicionada e limitada pela classe dominante, na grande maioria, constituída de senhores patriarcais vinculados à nobreza secular da posse e exploração das grandes propriedades rurais. José de Alencar provém dessa classe dominante, valorizando a ordem social, as instituições e os mecanismos que a asseguram e reproduzem, tais como o casamento, a família, a religião e o estado. A sua visão social do mundo é limitada pela ideologia da classe dominante e em decorrência disso não se abre para as inspirações do ritmo popular, mais especificamente em Lucíola. A fisionomia nacional expressada em Lucíola é portanto limitada por uma linguagem e ideologia condicionadas pela classe dominante. $O$ caráter nacional no romance surge a partir da luta de linguagens e posturas diversas, e por vezes, antagônicas e limitadas por diferentes ideologias: patriotismo romântico, tradicionalismo, evolucionismo e capitalismo, entre outras. $O$ nacional se constrói a partir de um movimento tensional da linguagem que ora repudia, ora exalta tanto os valores locais quanto os valores importados. Julgamentos de valor, por parte das personagens e do autor, incidem sobre a realidade nacional e os valores estrangeiros, ora valorizando-os, ora denegrindo-os. Seguindo uma ótica romântica ufanista, José de Alencar constrói para suas personagens determinados discursos que exaltam a natureza nacional. Essas personagens que perpassam o romance saltam do texto narrativo, demonstrando claramente seu objetivo de caracterizar a realidade nacional de uma forma exaltativa:

- Da Europa. Apenas desembarquei, meti-me num carro, e fui

passear. Vinte dias embarcada! Sabe o que é isso? Tinha saudade

das árvores e dos campos de minha terra, que eu não via há oito

meses! Que passeios encantadores por aquelas quintas cobertas de mangueiras que bordam as margens do rio! (Lucíola, p. 253) 
admirar

algumas das brilhantes parasitas que pendem dos ramos

das

árvores, abrindo ao sol a rubra corola?

(Lucíola, p. 250)

Saindo vi sentada na porta do seu camarote uma das poucas

loretes de Paris, que por um belo dia de inverno, como verdadeiras aves de arribação, batem as asas, atravessam o Atlântico, e vêm

esponejar-se ao sol do Brasil nas margens risonhas da mais

bela baía do mundo.

(Lucíola, p. 324)

O novo ano tinha começado. A bonança que sucedera às grandes

chuvas trouxera um dos sorrisos de primavera, como costumam

desabrochar no Rio de Janeiro dentre as fortes trovoadas do estio.

As árvores cobriram-se da nova folhagem de um verde tenro; o campo aveludava e na macia pelúcia da relva, e as frutas dos cajueiros se douravam aos raios do sol.

(Lucíola, p. 358)

Essas passagens enquadram-se dentro da filosofia do romantismo patriótico que deseja construir uma nação, encontrando na natureza os elementos para essa construção. A pátria é contaminada pela natureza que é exaltada em sua pujança e beleza natural. $O$ descritivismo, a cor local, o encanto pelo pitoresco se justificam à medida que a literatura brasileira oitocentista é uma literatura em formação e de descoberta que em tudo precisa reconhecer a realidade do país tão recentemente tornando independente de Portugal. Em contraposição a esse deslumbramento pela natureza pátria, encontramos outros discursos que desvalorizam os valores locais, apontando a cultura e o provincianismo do meio. $O$ escritor não permanece alheio à penúria cultural do meio, revelando o reduzido número e a escassez de manifestações culturais na corte. A sociedade fluminense é retratada como local insípido e estagnado, constituída por uma casta de indivíduos provincianos, ociosos e maledicentes:

Demais, se o livro cair nas mãos de alguma das mulheres que lêem neste país, ela verá estátuas e quadros da mitologia, a que não falta nem o véu da graça, nem a figueira, símbolos do pudor no Olimpo e no Paraíso terrestre.

(Lucíola, p. 243)

Apesar de minhas instâncias, Lúcia recusava ir ao teatro, sair a

passeio, ou gozar de alguns dos poucos divertimentos que the

oferecia esta insípida cidade.

(Lucíola, p. 289)

Há aqui no Rio de Janeiro certa classe de gente que se preocupa

mais com a vida dos outros, do que com a sua própria; e em parte 
dou-Ihe razão; de que viveriam eles sem isso, quando têm

a alma

oca e vazia? Essa gente já sabe quem tu és, que fortuna

tens,

quanto ganhas, onde moras e como vives.

(Lucíola, p. 300)

A incultura do meio, o atraso cultural da população em geral, a veneração pela literatura erudita estrangeira (marca de dependência cultural), o condicionamento de classe aprisionando a visão social do escritor, fazem-no repudiar a cultura popular. A cultura do povo praticamente não encontra espaço no romance Lucíola e quando é resgatada sofre um processo de desvalorização e depreciação. A cultura popular, o folclore e as canções populares não auxiliam, em Lucíola, a formação e a construção de uma identidade nacional. O romantismo de José de Alencar se distancia do romantismo político alemão que trabalhou em prol do resgate das tradições populares para a formação da nação alemã. Em Lucíola, notamos que a cultura do povo só ganha foros estéticos e valor social à proporção que se desvincula do povo e é reelaborada por uma ótica diferente da visão popular:

\author{
Muitas vezes achava Lúcia cosendo e cantando à meia \\ voz alguma \\ monótona modinha brasileira, que só a graça de uma \\ bonita boca, e a melodia de uma voz fresca, pode tornar \\ agradável.
}

(Lucíola, p. 342)

O provincialismo e o apego a uma visão tradicionalista se chocam, na sociedade fluminense oitocentista, com os valores burgueses que lutam para se impor, principalmente os da classe de mercadores, comerciantes, capitalistas, assalariados, profissionais liberais que se fortalecem ou se multiplicam nessa fase de transição de uma ordem rural-colonial para uma ordem burguesa. Os valores burgueses perturbam o ordem colonial e sacodem a estagnação e pasmaceira da sociedade fluminense que, presa à antiga ordem, resiste a uma nova realidade. Essa luta entre o velho e o novo se manifesta no romance Lucíola por intermédio da retratação, às vezes, negativa da classe burguesa emergente. Essa repulsa, algumas vezes, expressa-se na contraposição cidade/campo. O campo é idealizado como local puro e natural, contrapondo-se à cidade que é depreciada,revelando-se enquanto um espaço perigoso, licencioso e desvirtuador do indivíduo. Esta contraposição filia-se tanto a uma ideologia romântica rousseauniana quanto à visão social de mundo do romancista que se encontra em conflito entre a ordem colonial rural e a nova ordem burguesa emergente.

A ordem burguesa, seus valores e os indivíduos apegados a ela são, na maioria das vezes, retratados de uma maneira negativa. O romancista em Lucíola capitaliza sua aversão à ordem burguesa, construindo a personagem "Sr. Couto" que concentra em si vulgaridade, grosseria e limitação decorrentes diretamente de sua ótica burguesacapitalista. O escritor carrega na tinta, caricaturizando a personagem que se revela totalmente determinada, reduzida e limitada pelo pensamento economicista que reduz tudo e todos a mercadorias. A personagem "Sr. Couto" é um capitalista, diretamente responsável pela prostituição da personagem Lucíola. As relações sociais travadas entre o "Sr. Couto" e as outras personagens são reificadas, guiando-se sempre por uma política que espelha as relações burguesas de mercado, ou seja, são reduzidas a trocas de coisas que são avaliadas de acordo com o "lucro" que possam originar. As transformações sociais e econômicas advindas da instauração de uma mentalidade burguesa são repudiadas pelo escritor, que expressa seu desprezo na caracterizaçãocaricatura de determinadas personagens que sintetizam os novos valores. Porém, esse repúdio atinge outras áreas, além do universo das personagens. A economia burguesa propicia uma maior vitalidade do comércio e uma maior circulação de bens de mercado que geram certa abundância de mercadorias que passam a ser consumidas e adquiridas por um número maior de indivíduos. Essa democratização do consumo atinge também os bens culturais que podem ser reproduzidos em série, facilitando e barateando sua 
aquisição. O escritor não acolhe com bons olhos essa "proletarização" dos bens culturais e por intermédio de seu personagem "Paulo", revela uma visão classista, exclusivista e tradicional em relação à arte:

\author{
Quando eu lia a descrição de duas cabanas e a infância \\ dos \\ amantes, Lúcia deixou pender a cabeça sobre o seio, \\ cruzou as \\ mãos nos joelhos dobrando o talhe, como a estatueta da \\ Safo de \\ Pradier que por aí anda tão copiada em marfim e \\ porcelana.
}

(Lucíola, p. 336)

A questão do trabalho no romance Lucíola se apresenta sob diferentes ângulos portadores de ideologias diferentes e, por vezes, antagônicas. Ocorre a aceitação do trabalho enquanto elemento propiciador da emancipação individual e da dignificação do indivíduo, reforçando um dos mitos burgueses em relação ao trabalho revestido de positividade. Por outro lado, temos outros discursos no romance que depreciam e desvalorizam o trabalho. Essa postura justifica-se porque se prende à ideologia da classe dominante que sobrevive às custas do regime de escravidão e que concebe 0 trabalho como realidade essencialmente ligada à vida escrava ou aos pequenos assalariados, desprovidos, portanto, de prestígio social. Porém, essa visão negativa entra em choque com a realidade brasileira oitocentista que vê crescerem seus quadros de profissionais liberais, especialmente os bacharéis. As personagens masculinas em Lucíola são na sua grande maioria desvinculadas da nobreza da terra, tendo que sobreviver na cidade mediante esforço pessoal. Essas personagens são geralmente profissionais liberais que atingem 0 sucesso econômico e o ascenso social pelo trabalho. Embora não se negue a possibilidade de ascenso social via trabalho, esse ainda é repudiado no romance porque se revela como limitador do tempo de lazer, de ócio e de prazer. As personagens oscilam entre a exaltação e a repulsa em relação ao trabalho. Organizam e planificam suas atividades de modo a conciliar prazer/trabalho, demonstrando terem incorporado uma mentalidade verdadeiramente burguesa. Porém, notamos um certo sentimento de melancolia em relação a essa divisão do tempo do lazer e do tempo do trabalho que obedece a uma racionalidade que acaba por fragmentar, compartilhar e dividir a vida do indivíduo em fases e etapas estanques. A relação "Lucíola/Paulo" caracteriza bastante bem essa situação visto que "Paulo" separa sua vida em duas etapas distintas: numa 1a fase que comporta prazer em companhia de "Lucíola" e numa $2^{\underline{a}}$ fase que comporta trabalho e profissionalismo, mas sem "Lucíola":

\author{
Era bem pobre; mas estava independente, formado, no \\ ardor da \\ mocidade e sem encargos de família. Já tinha a intenção \\ de estabelecer-me aqui; antes de começar a vida árida e o \\ trabalho sério do homem que visa o futuro, queria dar um \\ último e esplêndido banquete às extravagâncias da \\ juventude. \\ (Lucíola, p. 284)
}

No campo da valorização do trabalho, temos a situação da personagem "Lucíola" logo após o seu processo de regeneração. A personagem "Lucíola", após abandonar a prostituição, muda-se para a periferia da cidade e passa a trabalhar. $O$ trabalho aqui é extremamente funcional, reforçando e confirmando a tentativa de regeneração da personagem. O trabalho de "Lucíola" prende-se, porém, às condições materiais e provincianas do meio fluminense oitocentista, visto que é artesanal (bordado, crochê) e ainda comporta uma dimensão de singularização do trabalhador. Portanto, devido ao próprio meio, não equivale ao trabalho industrial do mundo capitalista, extremamente despersonalizante.O tratamento dispensado à questão da passagem do trabalho escravo ao trabalho livre e pago, caracteriza, ainda, uma mentalidade fechada, preconceituosa e 
tradicionalista que não aceita as inovações burguesas referentes aos modos de produção e de relações de trabalho:

\begin{abstract}
- Esse homem é quase criado. A palavra produziu o seu efeito: desde que o Jacinto desceu ao mister de homem assalariado, não fiz mais reparo na sua assiduidade. Quase sempre 0 encontrava na sua escada interior;descendo quando eu subia; dava-Ihe tanta atenção como ao carroceiro que enchia as talhas d'água, ou ao cozinheiro que saía às compras.
\end{abstract}

(Lucíola, p. 345)

Finalmente, deixamos como último elemento a ser analisado, a oposição campo/cidade,mencionada anteriormente. Essa oposição vem reforçar e confirmar o conflito existente, na sociedade brasileira oitocentista, entre valores tradicionais secularmente estabelecidos e padrões citadinos e cosmopolitas. A valorização do campo liga-se tanto à mentalidade da classe dominante, de raízes rurais, quanto à visão idealista e romântica do filósofo francês Rousseau. Por outro lado, o romance apresenta também os aspectos positivos da realidade citadina, especificamente da corte e de tudo o que gira em torno dela. A corte "tem mil seduções que arrebatam o provinciano", no dizer da personagem-narrador, e oferece, portanto, muitas oportunidades inexistentes nas cidades interioranas. Há mais oportunidades de empregos, circulação de variadas mercadorias, entretenimento diversificado como teatro, baile, festas populares. Porém, a corte é também, segundo a personagem-narrador, "um país onde se envelhece depressa", devido à dinâmica e transformação constante da vida e dos costumes. Além disto, a corte abriga os mais variados tipos sociais sem lhes cobrar uma postura ética moral e política condizentes com uma mentalidade que valoriza família, casamento, estado, pátria. Essa relativização de valores é bastante característica dos meios citadinos e a personagem "Lucíola" é prova cabal dessa realidade tão diferente da realidade rural e interiorana. "Lucíola" se desloca com a família para o espaço citadino, prostituindo-se e passando a freqüentar os mesmos espaços que as consideradas "boas famílias" freqüentavam. Apesar dos perigos e dos inconvenientes do meio citadino, o escritor reluta em condenálo talmente. Muitas vezes ocorre um deslumbramento em relação à cidade, enfatizando o refinamento de hábitos e comportamentos adquiridos num ambiente cosmopolita. "Lucíola" ao regenerar-se, muda para os arrabaldes para levar uma vida pacata e tranqüila, mas conserva a experiência mundana, conseguida na corte que antes de depreciá-la, a valoriza:

\author{
Lúcia conservava do mundo a elegância e a distinção, que \\ se \\ tinham por assim dizer impresso e gravado na sua \\ pessoa. Fora \\ disto ninguém diria que esta moça vivera algum tempo \\ numa \\ sociedade livre. As suas idéias tinham a ingenuidade dos \\ quinze \\ anos; e às vezes ela me parecia mais infantil, mais \\ inocente do \\ que Ana com toda a sua pureza e ignorância. \\ (Lucíola, p. 356)
}

Embora ocorra a idealização do campo e das cidades afastadas da vida mundana e dinâmica do meio urbano, este último também recebe um processo de valorização. Justifica-se o encantamento pela cidade à medida que para esta concorre 0 influxo civilizatório, transplantado para a provinciana sociedade fluminense, o padrão parisiense idolatrado pela elite brasileira oitocentista. $O$ deslumbramento perante Paris reforça a dependência cultural brasileira para amenizar um sentimento de inferioridade que tenta equipar a realidade da província com a realidade parisiense. O caráter nacional, portanto, passa a ser o resultado da tensão existente entre valores locais e valores importados, 
reforçando ora as diferenças ora as semelhanças, chegando, às vezes, a enfatizar semelhanças esdrúxulas, como:

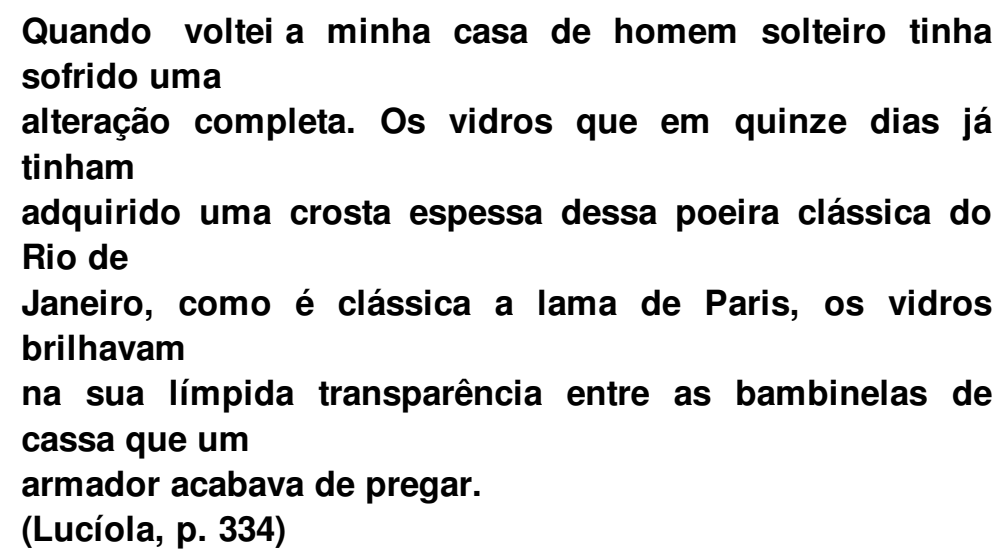

\section{CONCLUSÃO}

No romance Lucíola, temos uma representação da realidade nacional, mais especificamente do centro urbano do Rio de Janeiro de meados do século XIX, plasmada numa forma artística determinada e conformada diretamente pela visão social do escritor José de Alencar que também faz parte dessa realidade. O ficcionista expressa, principalmente a partir das falas do narrador e das demais personagens os conflitos entre valores locais e valores importados, revelando o nacional como produto do entrechoque de culturas diferentes. O romancista, apegado à visão de um mundo da classe dominante de raízes rurais oscila entre a aceitação e o repúdio aos valores burgueses importados. $A$ sua posição privilegiada de intelectual the permite ver e sentir a incultura e o provincianismo da realidade local e isso o leva, muitas vezes, a depreciar o meio nacional e a idealizar os valores burgueses, representantes de um outra realidade que se revela mais ampla e mais rica que a local. Porém, o compromisso do escritor José de Alencar em construir uma identidade nacional, via expressão literária, manifesta-se e confirma-se claramente na valorização local e também na aceitação bastante lúcida e moderna da realidade local enquanto resultado do conflito entre o velho e o novo. Segundo o narrador "Paulo" do romance Lucíola, o objeto central de sua narrativa é a caracterização de "um perfil de mulher", manifestando clara configuração psicológica de sua narrativa. Porém, como vimos, o romance extrapola esse projeto ao configurar-se também enquanto um painel da época bastante verossímil. O compromisso social de José de Alencar em criar uma identidade nacional literária altera os planos da personagem-narrador. $\mathrm{O}$ autor isola parte da realidade nacional, liberando-a e recriando-a através de uma forma artística teleguiada pelo compromisso de fabricar uma fisionomia da sociedade brasileira fluminense que surge como um amálgama conflitante entre valores locais e importados.

NOTAS DE REFERÊNCIA

1. ALENCAR, José. Lucíola. Obras completas de José de Alencar, s. ed., 1970, 7 V. Às demais citações desta obra correspondem a esta edição e virão sempre indicadas pelo título Lucíola e o respectivo número da página onde se encontra a citação.

2. CÂNDIDO, Antônio. Formação da literatura brasileira: momentos decisivos. 6. ed. Belo Horizonte, Ed. Itatiaia, 1981. V. As demais citações desta obra correspondem a esta edição e virão sempre indicadas pelo título reduzido para FLB e o respectivo número da página onde se encontra a citação.

3. HOLANDA, Sérgio Buarque de. Raízes do Brasil. 19., ed. Rio de Janeiro, José Olympio, 1987. As demais citações desta obra correspondem a esta edição e virão sempre indicadas pelo título reduzido para RB e o respectivo número da página onde se encontra a citação.

4. ALENCAR, José. Sonhos d'Ouro. 8. ed., São Paulo, Melhoramentos S. d. As demais citações desta obra correspondem a esta edição e virão sempre indicadas pelo título reduzido para $\mathrm{SO}$ e o respectivo número da página onde se encontra a 
citação.

5. COUTINHO, Afrânio, org. A Polêmica Alencar-Nabuco. 2. ed., Rio de Janeiro, Tempo Brasileiro, Brasília, Ed. Universidade de Brasília, 1978. As demais citações desta obra correspondem a esta edição e virão sempre indicadas pelo título reduzido para PA-B e o respectivo número da página onde se encontra a citação.

\section{REFERÊNCIAS BIBLIOGRÁFICAS}

1. ALENCAR, José. Lucíola. Obras completas de José de Alencar, s. ed., 1970, 7V.

2. . Sonhos d'Ouro. 8 ed. São Paulo. Melhoramentos, s. d.

3. BORNHEIM, Gerd et alii. Tradição / Contradição. Rio de Janeiro, Jorge Zahar, 1987.

4. BOSI, Alfredo. História concisa da literatura brasileira. 3. ed. São Paulo, Cultrix.

5. CÂNDIDO, Antônio. Formação da literatura brasileira. Momentos decisivos. 6. ed., Belo

Horizonte, Ed. Itatiaia, 1981, V. 2.

6. COUTINHO, Afrânio, org. A Polêmica Alencar-Nabuco. 2. ed. Rio de Janeiro, Tempo Brasileiro,

Brasília, Ed. Universidade de Brasília, 1978.

7. HOLANDA, Sérgio Buarque de. Raízes do Brasil. 19. ed. Rio de Janeiro, José Olympio, 1987. 